\title{
IMPLEMENTASI MANAJEMEN PENDIDIKAN KARAKATER ISLAMI DALAM MEWUJUDKAN AKHLAK PESERTA DIDIK DI SDIT TAHFIZH QUR'AN AL - JABAR TELUKJAMBE BARAT KARAWANG
}

\author{
Lala Nurlatifah \\ Universitas Singaperbangsa Karawang \\ Korespondensi: Jl. HS.Ronggo Waluyo, Puseurjaya, Kec. Telukjambe Tim., Kabupaten Karawang, \\ Jawa Barat 41361 \\ e-mail: 1610631120038@student.unsika.ac.id
}

1202

\begin{abstract}
A bad moral that continues and seems increasingly out of control and undirected. Impairment of personal qualities that are not good by the successor of this nation occurs in all aspects, ranging from speaking, how to dress and also behavior. For that character education is very important to be instilled especially in schools by using the management of character education itself well. This study aims to determine the implementation of character education management in SDIT Tabfiøh Qur'an Al-Jabar Telukjambe Barat Karawang in an effort to realize the morals of students. use the description method with a qualitative approach. Data collection is done by documentation, observation, interviews related to the object being examined. Then analyzed using qualitative descriptive analysis. The results of this study are that (1) Planning for character education at SDIT Tabfizh Qur'an is carried out through a meeting at the beginning of the year by involving many parties both teachers, staff, other employees and parents (2) implementing character education at SDIT Tabfizh Qur'an Al-Jabar through integration of character values into subject matter, teacher training by inviting experts, curriculum additions or improvements, teacher habituation and exemplary (3) evaluation (assessment) of character education management in SDIT Tabfirh Qur'an Al-Jabar ie the principal evaluates one week two times to each class and students are given an evaluation book when doing activities at home.
\end{abstract}

Keywords: Management, Character Education, Students.

\section{PENDAHULUAN}

Pendidikan merupakan upaya yang terencana dalam proses pembimbingan dan pembelajaran bagi individu agar tumbuh berkembang menjadi manusia yang mandiri, bertanggung jawab, kreatif, berilmu, sehat, dan berkarakter mulia. Undang-undang 20 Tahun 2003 tentang Sistem Pendidikan Nasional (Sisdiknas) menegaskan:

"Pendidikan nasional berfungsi mengembangkan kemampuan dan membentuk watak serta peradaban bangsa yang bermartabat dalam rangka mencerdaskan kehidupan bangsa, bertujuan untuk berkembangnya potensi peserta didik agar menjadi manusia yang beriman dan bertakwa kepada Tuhan Yang Maha Esa, berakhlak mulia, sehat, berilmu, cakap, kreatif, mandiri, dan menjadi warga negara yang demokratis serta bertanggung jawab (Pasal 3)". (Marzuki, 2019: 3)

Dari rumusan tersebut terlihat bahwa pendidikan nasional mengemban misi yang tidak ringan, yaitu membangun manusia yang utuh dan paripurna yang memiliki nilai-nilai karakter yang agung di samping juga harus memiliki fondasi keimanan dan ketakwaan Implementasi Manajemen Pendidikan Karakter Islami... 107 
yang tangguh. Oleh karena itu, pendidikan menjadi agent of change yang harus mampu melakukan perbaikan karakter bangsa.

Dengan demikian tidaklah berlebihan jika dikatakan bahwa misi utama dari kerasulan Nabi Muhammad SAW adalah untuk menyempurnakan akhlak yang mulia, dan sejarah mencatat bahwa faktor pendukung keberhasilan dakwah Nabi antara lain karena dukungan akhlaknya yang mulia, sehingga Allah SWT sendiri memuji akhlak mulia Nabi Muhammad SAW. Sebagaimana Firman-Nya dalam Al-Qur'an surat AlAhzab ayat 21:

Sesunggubnya telah ada pada (diri) Rasulullah itu suri teladan yang baik bagimu (yaitu) bagi orang yang mengharap (rahmat) Allah dan (kedatangan) hari kiamat dan dia banyak menyebut Allab

Dari paparan di atas mengenai penjelasan pendidikan karakter secara umum dan karakter yang terjadi pada zaman sekarang ini, Jika dikaitkan dengan kondisi riil di SDIT Al-Jabar yang menjadi observasi awal bagi peneliti adalah peserta didik yang masih terlihat dini mereka sudah mampu menghafal juz 30 dalam Al-Qur'an. Kegiatan tersebut merupakan suatu hal yang perlu di tiru oleh banyak orang, karena awalnya mereka memang melakukan hal tersebut dengan paksaan karena ada tuntutan oleh pihak kurikulum, tetapi dengan pembiasaan setiap saat peserta didik akan menyadari, menginsafi, dan melakukannya bahwa semua itu bukan lagi beban atau tuntutan semata. Karena demikian itu bahwa sejatinya pendidikan karakter membantu menumbuhkembangkan jiwa peserta didik baik lahir maupun batin, dari sifat kodratinya menuju ke arah peradaban yang manusiawi dan lebih baik serta terwujudnya pribadi yang religius dan mampu mengamalkan akhlak yang baik dalam kehidupan sehari-hari. Selain itu pendidikan karakter yang diterapkan di SDIT Al-Jabar adalah muroja'ah hadits-hadits Nabi, melaksanakan kegiatan salat sunah duha, melaksanakan kegiatan salat fardh dzuhur dan ashar secara berjemaah dan membaca doa serta muroja'ah kembali juz 30 sebelum melaksanakan Kegiatan Belajar Mengajar (KBM). Hal tersebut merupakan cerminan dari salah satu nilai pendidikan karakter yaitu Religius. Selain itu, di SDIT Al-Jabar setiap masing-masing peserta didik mempunyai buku penghubung yang khusus untuk dilaksanakan ketika di rumah, buku panduan tersebut berisi salat 5 waktu, doa sehari-hari misalnya doa hendak makan, tidur dan bangun tidur. Dan setiap hari buku tersebut dibawa ke sekolah kemudian diberikan kepada guru kelas masing-masing. Hal tersebut merupakan konsep terencana dalam proses pembimbingan dan pembelajaran bagi masing-masing peserta didik di SDIT Al-Jabar agar tumbuh berkembang menjadi manusia yang mandiri, bertanggung jawab, kreatif, berilmu, jujur, disiplin dan berkarakter mulia. Para peserta didik juga diajari sopan santun, berkomunikasi yang baik, berpakaian rapi, masuk sekolah tepat waktu dan pulang tepat waktu semua itu merupakan proses menumbuhkembangkan jiwa menjadi seorang yang disiplin.

\section{PENGERTIAN MANAJEMEN PENDIDIKAN KARAKTER ISLAMI}

Dalam perspektif Islam, pendidikan karakter secara teoritik sebenarnya telah ada sejak Islam diturunkan di dunia, seiring dengan diutusnya Nabi Muhammad SAW untuk memperbaiki atau menyempurnakan akhlak (karakter) manusia. Ajaran Islam 
sendiri mengandung sistematika ajaran yang tidak hanya menekankan pada aspek keimanan, ibadah dan mu'amalah, tetapi juga akhlak. Pengamalan ajaran Islam secara utuh (kaffah) merupakan model karakter seorang muslim bahkan dipersonifikasikan dengan model karakter Nabi Muhammad SAW, yang memiliki sifat Shidiq, Tabligh, Amanah, Fathonah. (Mulyasa, E 2018: 5)

Pendidikan karakter yang digambarkan Al-Qur'an sebagaimana tersebut di dalam Al-Qur'an telah dipraktikkan oleh Nabi Muhammad SAW. Ketika Siti Aisyah ditanya tentang akhlak Rasulullah SAW., ia menjawab, bahwa akhlak Rasulullah SAW. itu adalah AlQur'an. Abu Hasan Aliya al-Nadwiy dalam bukunya Madza Khasira al-Alam bi Inbithath almuslimin (Apa Kerugian Dunia Akibat Kemerosotan Umat Islam), berkata, bahwa Muhammad bin Abdullah diutus Allah SWT. sebagai Nabi dan Rasul tepat dalam keadaan dunia laksana suatu bangunan yang baru saja di goncang gempa yang dahsyat, sehingga semua isinya berantakan tidak berada pada tempat yang semestinya. Ada sebagian dari tiang-tiang dan perkakasnya yang rusak dan hancur; ada yang miring dan bengkok; ada yang bergeser dari tempatnya semula pindah ke tempat lain yang tidak pantas; dan ada juga yang tumpang tindih saling bertumpuk. (Nata Abuddin, 2017: 269).

\section{PERENCANAAN PENDIDIKAN KARAKTER}

Perencanaan merupakan keseluruhan proses pemikiran penentuan semua aktivitas yang akan dilakukan pada masa yang akan datang dalam rangka mencapai tujuan, untuk itu diperlukan kemampuan untuk mengadakan visualisasi dan melihat ke depan guna merumuskan suatu pola tindakan untuk masa mendatang. Dengan adanya perencanaan yang matang maka akan mendukung perolehan hasil yang maksimal dan memudahkan langkah-langkah menuju pencapaian tujuan yang telah ditetapkan. Perencanaan merupakan langkah awal dalam proses manajemen. Perencanaan merupakan suatu proses penentuan tujuan pedoman pelaksanaan, dengan memilih yang terbaik dari alternatif-alternatif yang ada.

Karakter-karakter tersebut harus diwujudkan dalam pendidikan karakter di sekolah, dan untuk mewujudkan karakterkarakter tersebut ada proses yang harus dilaksanakan.

Komponen-komponen yang terdapat dalam manajemen pendidikan karakter di sekolah antara lain:

1) Kurikulum

Dalam pendidikan karakter, muatan kurikulum yang direncanakan tidak hanya dilaksanakan di dalam kelas semata namun perlunya penerapan kurikulum secara menyeluruh (holistik), baik dalam kegiatan eksplisit yang diterapkan dalam ekstra kurikuler, maupun kokurikuler, dan pengembangan diri.

Kurikulum sendiri merupakan ruh sekaligus guide dalam praktik pendidikan di lingkungan satuan sekolah. Gambaran kualifikasi yang diharapkan melekat pada setiap lulusan sekolah akan tercermin dalam racikan kurikulum yang dirancang pengelola sekolah yang bersangkutan. Kurikulum yang dirancang harus berisi tentang grand design pendidikan karakter, baik berupa kurikulum formal maupun bidden curriculum, kurikulm yang dirancang harus mencerminkan visi, misi dan tujuan sekolah yang berkomitmen terhadap pendidikan karakter. (Mulyasa E , 2018: 71)

Implementasi Manajemen Pendidikan Karakter Islami... 109 
Langkah-langkah dalam mengembangkan kurikulum pendidikan karakter antara lain:

1. Mengidentifikasi dan menganalisis permasalahan pendidikan karakter

2. Merumuskan Visi Misi dan Tujuan sekolah

3. Merumuskan indikator perilaku peserta didik

4. Mengembangkan silabus dan rencana pembelajaran berbasis pendidikan karakter

5. Mengintegrasikan konten kurikulum pendidikan karakter ke seluruh mata pelajaran

6. Mengembangkan instrumen penilaian pendidikan untuk mengukur ketercapaian program pendidikan karakter

7. Membangun komunikasi dan kerja sama sekolah dengan orang tua peserta didik.

2) Pengelolaan

Komponen pengelolaan yaitu sumber daya manusia (SDM) yang mengurus penyelenggaraan sekolah, menyangkut pengelolaan dalam memimpin, mengkoordinasikan, mengarahkan, membina serta mengurus tata laksana sekolah untuk menciptakan budaya sekolah berbasis pendidikan karakter. Termasuk dalam komponen sekolahan adalah kepala sekolah, konselor, pustakawan, staf tata usaha, dan office boy. (Mulyasa, E 2018: 72)

3) Guru

Guru memegang peranan yang sangat strategis terutama dalam membentuk karakter serta mengembangkan potensi siswa. Keberadaan guru di tengah masyarakat bisa dijadikan teladan dan rujukan masyarakat sekitar. Bisa dikiaskan, guru adalah penebar cahaya kebenaran dan keagungan nilai. Hal inikah yang menjadikan guru untuk selalu on the right track, pada jalan yang benar tidak menyimpang dan berbelok, sesai dengan ajaran agama yang suci, adat istiadat yang baik dan aturan pemerintah.

Dalam proses belajar mengajar, guru mempunyai tugas untuk mendidik, mengajar, membimbing, mengarahkan, melatih, menilai dan mengevaluasi serta memberi fasilitas belajar bagi siswa untuk mencapai tujuan pendidikan karakter. Guru mempunyai tanggung jawab untuk melihat segala sesuatu yang terjadi dalam kelas untuk membantu proses perkembangan siswa. Penyampaian materi pelajaran merupakan salah satu kegiatan belajar sebagai suatu proses yang dinamis dalam segala fase dan proses perkembangan siswa.

4) Siswa

Siswa yaitu subjek belajar yang akan melalui proses transformasi nilai-nilai luhur dalam implementasi pendidikan karakter di sekolah. Dalam perencanaan karakter peserta didik hal yang perlu diperhatikan adalah tahap-tahap mengklasifikasikan pendidikan karakter terhadap peserta didik, karena tidak semua siswa diperlakukan sama, akan tetapi penanaman pendidikan karakter peserta didik yang diharapkan berjenjang sesuai umurnya.

\section{PELAKSANAAN MANAJEMEN PENDIDIKAN KARAKTER}

Pada umumnya pendidikan karakter menekankan pada keteladanan, penciptaan lingkungan, dan pembiasaan. Dengan 
demikian, apa yang dilihat, didengar, dirasakan dan dikerjakan oleh peserta didik dapat membentuk karakter mereka. Selain menjadikan keteladanan dan pembiasaan sebagai metode pendidikan utama, penciptaan iklim dan budaya serta lingkungan yang kondusif juga sangat penting, dan turut membentuk karakter peserta didik.

Penciptaan lingkungan yang kondusif dapat dilakukan melalui berbagai variasi metode sebagai berikut:

1. Penugasan

2. Pembiasaan

3. Pelatihan

4. Pembelajaran

5. Pengarahan, dan

6. keteladanan

Berbagai metode tersebut mempunyai pengaruh yang sangat besar dalam pembentukan karakter peserta didik. pemberian tugas disertai pemahaman akan dasar-dasar filosofinya, sehingga peserta didik akan mengerjakan berbagai tugas dengan kesadaran dan pemahaman, kepedulian dan komitmen yang tinggi. Setiap kegiatan mengandung unsur-unsur pendidikan, sebagai contoh dalam kegiatan kepramukaan, terdapat pendidikan kesederhanaan, kemandirian, kesetiakawanan dan kebersamaan. Kecintaan pada lingkungan dan kepemimpinan. Dalam kegiatan olahraga terdapat pendidikan kesehatan jasmani, penanaman sportivitas, kerja sama (team work) dan kegigihan dalam berusaha. Selain itu pelaksanaan pendidikan karakter juga dilakukan sebagai berikut:

1. Pendidikan karakter dilakukan secara terintegrasi ke dalam semua mata pelajaran. Integrasi yang dimaksud meliputi pemuatan nilai-nilai ke dalam substansi pada semua mata pelajaran dan pelaksanaan kegiatan pembelajaran yang memfasilitasi di praktikannya nilai-nilai dalam setiap aktivitas di dalam dan di luar kelas untuk semua mata pelajaran.

2. Pendidikan karakter juga diintegrasikan ke dalam pelaksanaan kegiatan pembinaan peserta didik.

3. Pendidikan karakter dilaksanakan melalui kegiatan pengelolaan semua urusan di sekolah yang melibatkan semua warga sekolah.

\section{EVALUASI PENDIDIKAN KARAKTER}

Penilaian hasil pendidikan karakter pada hakikatnya merupakan suatu kegiatan untuk mengukur perilaku (karakter) yang telah terbentuk. Pada umumnya hasil pendidikan karakter akan memberikan pengaruh dalam dua bentuk: (1) peserta didik akan memiliki perspektif terhadap kekuatan dan kelemahannya atas karakter yang diinginkan, (2) mereka mendapatkan bahwa karakter yang diinginkan itu telah meningkat baik setahap atau dua tahap, sehingga sekarang akan timbul lagi kesenjangan antara karakter yang sekarang dengan karakter yang diinginkan. Kesinambungan tersebut merupakan dinamika proses belajar sepanjang hayat, dan pendidikan karakter yang berkesinambungan. Dikatakan demikian karena kesenjangan itu akan terus berkembang sesuai dengan kebutuhan dan perkembangan zaman, dan hal tersebut perlu dikaji secara terus-menerus untuk mengetahui kecenderungan, dan kebutuhan berikutnya.

Hal yang harus diperhatikan dalam menilai hasil pendidikan karakter adalah sebagai berikut: pertama, apakah penilaian ini telah mengukur seluruh program pendidikan karakter. Kedua, apakah penilaian dilakukan secara rasional dan

Implementasi Manajemen Pendidikan Karakter Islami... 111 
efisien. Ketiga, apakah penilaian yang dilaksanakan telah mengukur standar nasional dan lokal yang kompleks dalam berbagai cara. Dalam hal ini, guru, warga sekolah, orang tua, dan seluruh anggota masyarakat perlu dilibatkan dalam menilai hasil belajar peserta didik dan keluaran program lainnya. Orang tua dan anggota masyarakat yang berpartisipasi dalam perencanaan dan penilaian hasil pendidikan karakter akan lebih menyadari tingkat kesulitan alami dari penilaian pendidikan karakter di sekolah.

Kerja sama dengan orang tua peserta didik untuk mendapatkan hasil pendidikan yang baik, maka sekolah perlu mengadakan kerja sama yang erat dan harmonis antara sekolah dan Orang tua peserta didik.

\section{METODOLOGI PENELITIAN}

Dalam menyelesaikan penelitian ini, peneliti menggunakan pendekatan deskriptif. Artinya, data yang dikumpulkan bukan berupa data angka, melainkan data yang berasal dari naskah wawancara, catatan lapangan, dokumen pribadi, catatan atau memo peneliti dan dokumen resmi lain yang mendukung. Tujuan menggunakan pendekatan kualitatif adalah agar peneliti dapat menggambarkan realita empiris di balik fenomena yang terjadi terkait dengan implementasi manajemen pendidikan karakter Islami dalam mewujudkan akhlak peserta didik di SDIT Tahfizh Qur'an AlJabar Karawang.

Metode penelitian kualitatif adalah metode penelitian yang berlandaskan pada filsafat postpositivisme, digunakan untuk meneliti pada kondisi obyek yang alamiah (sebagai lawan eksperiment) dimana peneliti adalah kunci, pengambilan sampel sumber data dilakukan secara puposive dan snowball, teknik pengumpulan dengan triangulasi (gabungan), analisis data bersifat induktif/ kualitatif, dan hasil penelitian kualitatif lebih menekankan makna daripada generalisasi. (Sugiyono, 2011: 15).

Alasan peneliti melakukan penelitian ini dengan metode kualitatif melalui pendekatan analisis deskriptif, dikarenakan data yang dikumpulkan serta analisa kesimpulannya disajikan dalam uraian katakata. Serta dalam mencari dan mengumpulkan data teknik yang dipakai sebagian besar diperoleh dari lapangan atau lokasi penelitian. Pemaparan secara deskriptif ini juga dilakukan untuk menjelaskan sebuah karakteristik objek penelitian secara terperinci tanpa adanya pengaruh pendapat peneliti di dalam deskripsi tersebut. secara praktis penelitian kualitatif membuat peneliti lebih fleksibel dalam mengembangkan hasil temuan terutama dalam mendeskripsikan temuan hasil penelitian.

Teknik pengumpulan data menurut sugiyono (2015: 308) merupakan langkah yang paling utama dalam penelitian, karena tujuan pertama dari penelitian adalah mendapatkan data. Tanpa mengetahui teknik pengumpulan data, maka peneliti tidak akan mendapatkan data yang memenuhi standar data yang ditetapkan.

Dalam hal pengumpulan data ini, peneliti terjun langsung pada objek penelitian untuk mendapatkan data yang valid, maka peneliti menggunakan metode:

1) Observasi

\begin{tabular}{lrr}
\multicolumn{1}{c}{ Sutrisno Hadi (1986) } & dalam \\
Sugiyono, & 2015 & :193-205) \\
mengemukakan & bahwa, observasi \\
merupakan suatu proses kompleks, suatu & proses yang tersusun dari berbagai proses \\
proseras diantara &
\end{tabular}


yang terpenting adalah dari proses-proses pengamatan dan ingatan. Teknik pengumpulan data dengan observasi digunakan bila, penelitian berkenan dengan perilaku manusia, proses kerja, gejala-gejala alam dan bila responden yang diamati tidak terlalu besar.

Sedangkan menurut Imam Gunawan (2014: 143) Observasi merupakan suatu teknik pengumpulan data yang dilakukan dengan cara mengadakan penelitian secara teliti, serta pencatatan secara sistematis. Tujuan dari pengumpulan data dengan observasi ini biasanya untuk membuat deskripsi atas perilaku atau frekuensi atas suatu kejadian.

Pada penelitian ini, peneliti menggunakan metode observasi dengan secara langsung terjun ke lapangan untuk memperoleh data yang diinginkan. Observasi ini dilakukan peneliti dengan mengamati dan mencatat secara langsung kegiatan pelaksanaan manajemen pendidikan karakter dalam mewujudkan akhlak peserta didik di SDIT Tahfizh Qur'an Al-Jabar Telukjambe Barat Karawang yaitu meliputi perencanaan, pelaksanaan dan penilaian. Metode observasi ini, peneliti melakukan pada tanggal 10 Mei 2020.

2) Wawancara

Wawancara digunakan sebagai teknik pengumpulan data apabila peneliti ingin melakukan studi pendahuluan untuk menemukan permasalahan yang harus diteliti, dan juga apabila peneliti ingin mengetahui hal-hal dari responden yang lebih mendalam dan jumlah respondennya sedikit/kecil. Teknik pengumpulan data ini mendasarkan diri pada laporan tentang diri sendiri atau selfreport, atau setidak-tidaknya pada pengetahuan dan atau keyakinan pribadi.
Sutrisno hadi (1986) dalam Sugiyono (2015: 193-205) mengemukakan bahwa interview dan juga kuesioner (angket) adalah sebagai berikut:

a. Bahwa subyek (responden) adalah orang yang paling tahu tentang dirinya sendiri.

b. Bahwa apa yang dinyatakan oleh subyek kepada peneliti adalah benar dan dapat dipercaya.

c. Bahwa interpretasi subyek tentang pertanyaan-pertanyaan yang diajukan peneliti kepadanya adalah sama dengan apa yang dimaksudkan oleh peneliti.

Wawancara dapat dilakukan secara terstruktur maupun tidak struktur, dan dapat dilakukan melalui tatap muka (face to face) maupun dengan menggunakan telepon.

Sedangkan menurut Imam Gunawan (2015: 160) wawancara adalah suatu percakapan yang diarahkan pada suatu masalah tertentu dan merupakan proses tanya jawab lisan dimana dua orang atau lebih berhadapan secara fisik. Wawancara dilakukan untuk memperoleh data atau informasi sebanyak mungkin dan sejelas mungkin kepada subjek penelitian.

3) Dokumentasi

Dalam menggali berbagai informasi tentang implementasi manajemen pendidikan karakter dalam mewujudkan akhlak peserta didik di SDIT Tahfizh Qur'an Al-Jabar Telukjambe Barat Karawang, di samping menggunakan metode wawancara dan observasi, peneliti juga menggunakan metode studi dokumentasi. Studi dokumentasi yaitu teknik pengumpulan data yang dilakukan dengan cara mencari data mengenai halhal atau variabel yang berupa catatan, buku, majalah, surat kabar, notulen rapat 
dan sebagainya. Jadi studi dokumentasi ini digunakan untuk mendapatkan data yang berupa tulisan-tulisan yang berhubungan dengan objek penelitian yang akan dibahas dalam penelitian ini serta digunakan sebagai metode penguat dari hasl metode wawancara dan observasi. Teknik ini digunakan untuk memperoleh data tentang profil sekolah, visi, misi dan strategi di SDIT Tahfizh Qur'an Al-jabar Telukjambe Barat Karawang.

\section{HASIL PENELITIAN DAN PEMBAHASAN}

\section{Konsep Perencanaan Manajemen Pendidikan Karakter dalam Mewujudkan Akhlak Peserta Didik di SDIT Tahfizh Qur'an Al-Jabar Telukjambe Barat Karawang}

Perencanaan merupakan keseluruhan proses pemikiran penentuan semua aktivitas yang akan dilakukan pada masa yang akan datang dalam rangka mencapai tujuan.

Saat peneliti melakukan wawancara, peneliti menemukan bahwa perencanaan paling awal dalam pendidikan karakter di SDIT Tahfizh Qur'an Al-Jabar adalah penentuan tujuan. Hal ini terlihat saat kepala sekolah melaksanakan kegiatan rapat awal tahun yang melibatkan semua pihak baik itu guru, wali kelas, karyawan maupun pihak orang tua siswa tentang konsep perencanaan pendidikan karakter di SDIT Tahfizh Qur'an Al-Jabar dengan tujuan apa yang direncanakan dalam rapat bisa diterapkan dan dijalankan secara optimal dengan efektif dan efisien dan bertujuan agar siswa diharapkan dapat menanamkan nilai-nilai karakter melalui visi, misi dan program sekolah, keteladanan, pembiasaan, sloganslogan yang ada di sekitar lingkungan sekolah, dan adanya kegiatan ekstrakurikuler guna membentuk karakter dan akhlak mulia peserta didik di SDIT Tahfizh Qur'an AlJabar. Hal ini sesuai dengan teori:

Perencanaan paling awal dalam pendidikan karakter adalah dengan penentuan tujuan. Tujuan tersebut selaras dengan yang ada dalam buku Manajemen Pendidikan Karakter Karangan Mulyasa, E bahwa tujuan pendidikan karakter yaitu untuk meningkatkan mutu proses dan hasil pendidikan yang mengarah pada pembentukan karakter dan akhlak mulia peserta didik secara utuh, terpadu, dan seimbang, sesuai dengan standar kompetensi lulusan pada setiap satuan pendidikan. Melalui pendidikan karakter peserta didik diharapkan mampu secara mandiri meningkatkan dan menggunakan pengetahuannya, mengkaji dan menginternalisasikan serta mempersonalisasikan nilai-nilai karakter dan akhlak mulia sehingga terwujud dalam perilaku sejari-hari. Pendidikan karakter pada tingkat satuan pendidikan mengarah pada pembentukan budaya sekolah/madrasah, yaitu nilai-nilai yang melandasi perilaku, tradisi, kebiasaan sehari-hari, serta simbol-simbol yang di praktikan oleh semua warga sekolah/madrasah, dan masyarakat sekitarnya. Budaya sekolah/madrasah merupakan ciri khas, karakter atau watak, dan citra sekolah/madrasah tersebut di mata masyarakat luas. Mulyasa, E (2018: 9)

Dengan demikian berdasarkan dari hasil temuan yang dilakukan di SDIT Tahfizh Qur'an Al-Jabar Karawang tentang perencanaan manajemen pendidikan karakter dalam meningkatkan akhlak peserta didik sudah cukup baik, hal ini dapat dilihat saat peneliti melakukan wawancara dengan 
narasumber, selanjutnya peneliti memberi saran kepada pihak SDIT Tahfizh Qur'an Al-Jabar Telukjambe Barat Karawang untuk lebih meningkatkan lagi program-program budaya Islaminya agar menghasilkan peserta didik yang berakhlakul karimah, aktif, kreatif, inovatif dan penuh percaya diri.

\section{Pelaksanaan Manajemen Pendidikan Karakter dalam Mewujudkan Akhlak Peserta Didik di SDIT Tahfizh Qur'an} Al-Jabar Telukjambe Barat Karawang

Pelaksanaan bisa berjalan dengan optimal karena sebelumnya ada proses perencanaan yang melibatkan banyak pihak. Saat peneliti melakukan wawancara, observasi dan dokumentasi, peneliti menemukan bahwa pelaksanaan pendidikan karakter di SDIT Tahfizh Qur'an Al-Jabar yaitu melalui kegiatan pembiasaan seperti melaksanakan shalat dzuhur dan ashar secara berjemaah, shalat sunah dhuha rutin setiap pagi, tadarus dan murojaah Al-Qur'an, melakukan salam sapa dan berwudu ketika hendak datang

ke sekolah, dan berinfak yang dikenal dengan istilah Gerakan Sehari Seribu (Gasebu). Kemudian selain pembiasaan, pelaksanaan pendidikan karakter yang diterapkan di SDIT Tahfizh Qur'an yaitu dengan cara mengintegrasikan nilai-nilai karakter ke dalam semua materi pelajaran, melalui kegiatan ekstrakurikuler dan contoh keteladanan guru. Hal ini sesuai dengan teori:

Menurut Wiyani (yang diakses dari https://repository.uinsu.ac.id pada tanggal 14/06/20) berpendapat bahwa pelaksanaan merupakan kegiatan untuk merealisasikan rencana menjadi tindakan nyata dalam rangka mencapai tujuan secara efektif dan efisien. Sehingga akan memiliki nilai. Dalam buku Manajemen Pendidikan Karakter karangan
Mulyasa, E Pada umumnya pendidikan karakter menekankan pada keteladanan, penciptaan lingkungan, dan pembiasaan. Dengan demikian, apa yang dilihat, didengar, dirasakan dan dikerjakan oleh peserta didik dapat membentuk karakter mereka. Selain menjadikan keteladanan dan pembiasaan sebagai metode pendidikan utama, penciptaan iklim dan budaya serta lingkungan yang kondusif juga sangat penting, dan turut membentuk karakter peserta didik.

Dengan demikian berdasarkan dari hasil temuan yang dilakukan di SDIT Tahfizh Qur'an Al-Jabar Telukjambe Barat Karawang berkaitan dengan pelaksanaan pendidikan karakter di SDIT tersebut sudah berjalan cukup baik secara efektif dan efisien sesuai dengan teori yang terpapar di atas.

\section{Evaluasi (penilaian) Manajemen Pendidikan Karakter dalam Mewujudkan Akhlak Peserta Didik di SDIT Tahfizh Qur'an Al-Jabar Telukjambe Barat Karawang}

Setelah sesuatu yang direncanakan tercapai dan dilaksanakan dengan baik secara optimal adakalanya semuanya membutuhkan penilaian. Saat peneliti melakukan wawancara, peneliti menemukan bahwa penilaian pendidikan karakter di SDIT Tahfizh Qur'an Al-Jabar yaitu dengan cara yaitu mengacu pada nilai keseharian yang di dapat, kedua memperhatikan tingkah laku peserta didik, ketiga melihat perubahan karakter peserta didik, keempat memberikan nilai yang sesuai dengan perkembangan karakter peserta didik. kemudian selain itu kepala sekolah memonitor kepada guru satu minggu dua kali, dan bertanya pada guru tentang bagaimana perkembangan karakter peserta didiknya pada masing-masing kelas.

Implementasi Manajemen Pendidikan Karakter Islami... $\quad 115$ 
Dan guru juga membuat papan monitor karakter siswa, kemudian satu minggu sekali melalui kegiatan upacara mengumumkan misalnya kelas yang mendapat penghargaan baik, kelas yang bersih dan lain-lain. Selain itu Hasil laporan atau catatan perkembangan peserta didik sebagai wujud evaluasi terhadap pendidikan karakter, di SDIT AlJabar terdapat lembar evaluasi aktivitas siswa saat di rumah, kemudian esok harinya buku tersebut bisa di nilai oleh guru masingmasing kelas, hal itu juga dapat melatih kejujuran siswa saat di rumah. Hal ini sesuai dengan teori:

"Hal yang harus diperhatikan dalam menilai hasil pendidikan karakter adalah sebagai berikut: pertama, apakah penilaian ini telah mengukur seluruh program pendidikan karakter. Kedua, apakah penilaian dilakukan secara rasional dan efisien. Ketiga, apakah penilaian yang dilaksanakan telah mengukur standar nasional dan lokal yang kompleks dalam berbagai cara. Dalam hal ini, guru, warga sekolah, orang tua, dan seluruh anggota masyarakat perlu dilibatkan dalam menilai hasil belajar peserta didik dan keluaran program lainnya. Orang tua dan anggota masyarakat yang berpartisipasi dalam perencanaan dan penilaian hasil pendidikan karakter akan lebih menyadari tingkat kesulitan alami dari penilaian pendidikan karakter di sekolah". Mulyasa, E (2018: 200)

Dengan demikian berdasarkan dari hasil temuan yang dilakukan di SDIT Tahfizh Qur'an Al-Jabar terkait dengan evaluasi (penilaian) pendidikan karakter di SDIT Tahfizh Qur'an Al-Jabar yaitu cukup baik karena pihak kepala sekolah, guru dan orang tua saling bekerja sama untuk menghasilkan pendidikan yang berkarakter bagi peserta didiknya. dan masyarakat sekitar juga ikut berpartisipasi dalam perencanaan dan penilaian hasil pendidikan karakter agar lebih menyadari tingkat kesulitan alami dari penilaian pendidikan karakter di sekolah.

\section{PENUTUP}

\section{Kesimpulan}

Berdasarkan pemaparan hasil dan pembahasan penelitian di atas, maka dapat disimpulkan bahwa implementasi manajemen pendidikan karakter dalam mewujudkan akhlak peserta didik di SDIT Tahfizh Qur'an Al-Jabar Telukjambe Barat Karawang meliputi berbagai kegiatan dilakukan yaitu:

1. Perencanaan manajemen pendidikan karakter dalam mewujudkan akhlak peserta didik di SDIT Tahfizh Qur'an AlJabar Telukjambe Barat Karawang melalui kegiatan rapat awal tahun yang melibatkan banyak pihak mengenai pendidikan karakter yang akan diterapkan ditahun ajaran berikutnya yaitu tentang pembagian dengan rapat awal tahun bersama para guru dan pihak-pihak lainnya. Pada hari pertama tentang pembagian tugas mengajar wali kelas dan tugas menjadi guru kelas. Menjadi wali kelas tugasnya selain mengajar yaitu membuat administrasi kelas seperti membuat absensi, tata tertib kelas, dan media pembelajaran. sedangkan guru kelas selain tugasnya mengajar yaitu membantu membuat administrasi guru seperti membuat RPP dan silabus. Hari kedua tentang kurikulum pembelajaran atau konsep pembiasaan yang menerapkan nilai-nilai karakter, yang akan diterapkan pada tahun ajaran berikutnya. 
Dan biasanya dari pembiasaan-pembiasan tersebut setiap tahunnya ada yang ditambah atau diperbaiki seperti tahun lalu selain bersalaman dan menyapa saat datang ke sekolah siswa diharuskan untuk berwudu tanpa di monitor oleh wali kelas, sedangkan pada perencanaan tahun berikutnya yang dihasilkan rapat awal tahun ketika siswa datang ke sekolah diharuskan untuk berwudu dan di monitor langsung oleh wali kelas setiap bacaan doa dan tata cara wudunya. Sedangkan kurikulum yang diterapkan di SDIT Tahfizh Qur'an Al-Jabar ada dua kurikulum yaitu kurikulum tahun 2013 atau dikenal dengan sebutan K-13 kedua kurikulum lokal yaitu dari sekolah/yayasan sendiri. Hari ketiga mengundang pakar atau ahli baik tingkat Kabupaten atau Provinsi atau Nasional untuk pendidikan pembelajaran atau pembinaan guru guna mengambil ilmu dan pengalaman baru dari pembicara yang diundang. Dan hasil rapat yang diputuskan dituangkan dalam tata tertib yang akan berlaku di sekolah.

2. Pelaksanaan manajemen pendidikan karakter dalam mewujudkan akhlak peserta didik di SDIT Tahfizh Qur'an AlJabar Telukjambe Barat Karawang melalui pembiasaan-pembiasaan seperti melaksanakan shalat dzuhur dan ashar secara berjemaah, shalat dhuha rutin secara berjemaah, murojaah dan tadarus Al-Qur'an sesuai batasan masing-masing siswa, salam dan sapa kepada teman dan guru ketika datang ke sekolah, infak kelas yang dikenal dengan istilah gerakan sehari seribu (Gasebu), dan membaca doa di awal dan sesudah pembelajaran. Selain melalui pembiasaan pelaksanaan pendidikan karakter di SDIT Tahfizh Qur'an melalui contoh keteladanan (Uswatun Hasanab) serta mengintegrasikan nilai-nilai karakter ke dalam semua mata pelajaran.

3. Evaluasi (Penilaian) manajemen pendidikan karakter dalam mewujudkan akhlak peserta didik di SDIT Tahfizh Qur'an Al-Jabar Telukjambe Barat Karawang yaitu kepala sekolah memonitor kepada guru satu minggu dua kali, kemudian bertanya pada guru tentang bagaimana perkembangan karakter peserta didiknya pada masingmasing kelas. Dan guru juga membuat papan monitor karakter siswa, kemudian penilaian karakter juga dilaksanakan satu minggu sekali melalui kegiatan upacara.

\section{Saran}

Tanpa mengurangi rasa hormat kepada semua pihak dan demi suksesnya kegiatan implementasi manajemen pendidikan karakter dalam mewujudkan akhlak peserta didik agar berjalan lebih lancar dan memperoleh hasil yag maksimal, maka penulis memberikan saran, antara lain:

1. Pembentukan karakter peserta didik membutuhkan keseriusan yang sangat urgen. Untuk itu, membutuhkan manajemen pendidikan karakter dalam sekolah. Tujuannya adalah untuk mencetak generasi bangsa yang berkarakter yang sesuai dengan nilai agama, adat istiadat, budaya, bangsa dan negara.

2. Peningkatan sarana dan prasarana menjadi keharusan dan menjadi komitmen semua pihak, misalnya perbaikan bangunan, pembangunan ruang untuk beribadah, pembangunan

Implementasi Manajemen Pendidikan Karakter Islami... 117 
UKS, pembangunan perpustakaan yang lebih layak dan lain-lain guna memperlancar kegiatan program sekolah khususnya dalam mendukung pembentukan karakter siswa.

3. Harus ada usaha untuk meningkatkan kompetensi guru melalui pelatihan, pembinaan dalam kegiatan keagamaan. Dengan harapan guru lebih baik lagi di masa yang akan datang dan menjadi uswatun basanab untuk para pesera didik.

4. Harus ada usaha untuk terus meningkatkan komunikasi antar sekolah, yayasan dan orang tua. Dengan harapan orang tua paham dan mengetahui akan program sekolah secara mendetail, sehingga orang tua tidak ragu menyekolahkan putranya ke sekolah yang dipilih. Dengan komunikasi yang baik, secara tidak langsung orang tua ikut merasa tanggung jawab terhadap perkembangan sekolah khususnya dalam pembentukan karakter peserta didik.

5. Semua komponen yang terlibat baik dari internal sekolah SDIT Tahfizh Qur'an Al-Jabar Telukjambe Barat Karawang, maupun eksternal sekolah harus dilibatkan dalam upaya meningkatkan akhlak siswa agar target karakter peserta didik dan tujuan dari visi, misi SDIT Tahfizh Qur'an Al-Jabar Telukjambe Barat Karawang bisa tercapai sesuai yang diharapkan.

\section{KEPUSTAKAAN ACUAN}

Gunawan, Imam. 2015. Metode Penelitian kualitatif: Teori dan praktik. Jakarta: PT Bumi Aksara.
Iskandar, 2009. Metodologi Penelitian Pendidikan Dan Sosial: Kuantitatif dan Kualitatif. Jakarta: GP Press.

Marno dan Spuriyatno Triyo. 2008. Manajemen dan Kepemimpinan Pendidikan Islam. Bandung: pt Refiks Aditama

Marzuki. 2019. Pendidikan Karakter Islam. Jakarta: Amzah.

Moleong, Lexy. 2001. Metodologi penelitian Pendidikan. Bandung: PT Remaja Rosdakarya.

Mostari, Mohamad. 2018. Manajemen Pendidikan. Depok : Rajawali pers.

Mulyasa, E. 2018. Manajemen Pendidikan Karakter. Jakarta: Bumi Aksara.

Nata, Abuddin. 2017. Akblak Tasawuf dan Karakter Mulia. Jakarta: Rajawali pers.

Sugiyono, 2015. Metode Penelitian Pendidikan Pendekatan Kuantitatif, Kualitatif dan R\&D. Bandung: Alfabeta.

Sugiyono. 2020. Metode Penelitian Kualitatif. Bandung : Alfabeta.

Suyadi. 2018. Strategi Pembelajaran Pendidikan Karakter. Bandung: PT Remaja Rosdakarya.

Syukur, Abdillah Taufik. 2014. Pendidikan Karakter Berbasis Hadits. Jakarta: Rajawali Pers.

Umiarso dan Yuliharti. 2019. Manajemen Profetik. Jakarta: Amzah.

Yusuf, Muri. 2014. Metode Penelitian Kuantitatif, Kualitatif dan Gabungan. Jakarta: Fajar interprtama Mandiri. 